\title{
Studies and Explorations on the Cultivation Pattern of High-Level Applied Talents
}

\author{
Wanbin Ren \\ Dezhou University, Dezhou 253023, China \\ E-mail: rwb@dzu.edu.cn
}

\begin{abstract}
By learning about and analyzing many problems existing in the present cultivation of applied talents, this article puts forward some constructive thoughts including sticking to the "human-oriented" basis, converting the present educational ideas, conducting an all-round development, carrying out comprehensive quality education, sticking to harmonious development as demanded by economic and social development, sticking to sustainable development to realize a new leap in talent cultivation and make contributions to the economic construction as well as the construction of a well-off society.
\end{abstract}

\section{Keywords: Applied talents, Cultivation pattern}

With reform and development as the theme of modern China, it has been the general trend for schools to deepen their reform and development. As a result, during the process to be developed by facing themselves with the society, schools are expected to have right target orientation according to the demands of social development and schools' internal and external conditions, hence finding their distinguished and advantageous educational patterns which can sustain their power in fierce market competition. Under the new situation, schools should strength their construction of connotation to be adapted to the external environment to expand their space for survival and development. In addition, their outdated educational patterns should be replaced by scientific management ideas and methods to cultivate an array of overall coordinative, creative and sustainable high-quality applied talents with new ideas, systems and methods. As a result, they will have their special characteristics during their development. Only in this way will they gain an advantageous position in market competition.

\section{Being Fully Aware of the Importance and Necessity of Cultivating High-Level Applied Talents}

China's traditional education is intended to cultivate high-level professionals qualified for their majors and some relevant researches. For a while, this pattern provided a lot of qualified cadres, college teachers, accounting administrators and so on for Chinese society. At present, however, it is no longer adapted to China' current education and future development trends. Students have had a longing for their bright future since the very first day at college, only to find the distance between the reality and their dreams when they are faced with the fierce talent competition after their graduation. Having no access to their ideal jobs, unwilling to lower themselves, many graduates are stuck into confusion and hesitation. China Education Ministry once conducted a national questionnaire survey, distributing 1165 questionnaires to teachers in 10 sorts of universities including science and engineering, agriculture and forestry, medicine, finance, politics and law, teaching, Chinese, comprehensive universities and universities of nationalities in 7 areas including North China, Northeast China, East China , Central China, South China, Southwest China and Northwest China. $72.4 \%$ of the teachers involved in this survey think that the mainstream of China's talent cultivation should be that of applied compound talents. As is shown in 678 questionnaires distributed to working units, $51.3 \%$ of them think that the cultivation of students' abilities in analyzing and solving problems is most important. In our real practice, except those who further their study, all graduates are engaged in practical jobs, even including most postgraduates. Nowadays, what really appeals to working units is students' practical abilities, so some of them even refuse to enroll any fresh graduates. For example, among over 40,000 enterprises taking part in job fairs at a southern job market each year, only more than 1000 ones are interested in fresh graduates. Therefore, our traditional education is faced with a fierce challenge, that is, to reposition our cultivation target to cultivating high-quality applied talents conforming to social demands. 


\section{Strengthening the Cultivation of High-Level Applied Talents}

\subsection{Sticking to the "Human-Oriented" Basis and Converting Educational Ideas}

It offers a guarantee for the cultivation of high-level applied talents to convert present educational ideas and to establish a "human-oriented" educational idea. Actually, it is the nature and core of scientific development philosophy as well as the soul of talent cultivation to conduct the "human-oriented" idea, with which as the basis, a new educational idea emphasizing the development of individuality based on comprehensive quality will be conducted. As a consequence, the traditional educational ideas have to be reformed.

\subsubsection{Establishing Right Sense of Talents}

Our colorful world has led to various social demands as well as different dreams held by different people. Meanwhile, different talents are required in different fields of our society. As far as modern production is concerned, versatile talents with skills, knowledge and communicative abilities are in demand. As a result, schools, a place to cultivate talents and serve social development, are supposed to keep in step with the times. To be more specific, they should totally convert their educational ideas, encouraging students to strengthen their practical skills from primary school, to challenge authoritative things and question their teachers, to get along with others, to learn to be a good citizen instead of only focusing their attention on textbooks and exams. Nowadays, vocational education has become a significant part in China's education to overcome the international financial crisis, to adjust economic structure and to realize the development of China's economy with its output of various talents to the society. Therefore, our former idea that vocational education is inferior should give way to the right sense of talents.

\subsubsection{Converting the Cultivation of Specialized Talents into that of Compound Talents}

Because most applied talents will be employed by enterprises, they have to face specific characteristics and patterns in different enterprises. As a result, schools should broaden students' scope of knowledge by encouraging them to choose those interdisciplinary subjects suitable for their individual development, hence cultivating more compound applied talents.

\subsubsection{Converting Traditional Professional Education into Comprehensive Quality Education}

Compared with the traditional professional education, which neglects the cultivation of students' comprehensive quality in its teaching and assessment systems, hence producing talents lacking in abilities in adaptation, communication, innovation and potential as well as open-minded thoughts and organization abilities, comprehensive quality education pays more attention to students' overall development.

\subsubsection{Converting Full-Time Isolated Education into Open Social Practice}

Although the learning of theories, which is emphasized in former isolated education, is quite necessary, the constantly developing society has given new standards for knowledge and talents from time to time. Therefore, it will exert positive effects on teaching and learning as well as the conversion and development of educational ideas to prepare talents for the society with the conduction of practical education.

\subsubsection{Converting Passive Learning Pattern into Active Pattern}

In the traditional passive learning pattern, much importance is put on accepting and inheriting the existing knowledge instead of exploring knowledge in depth and width as well as new knowledge, hence failing to cultivate students' exploratory and innovative spirits. Modern education, however, giving priority to creativity and innovation, encourages students to explore knowledge in depth and width and to accept new knowledge actively. The conversion of learning pattern is a source from which creativity and innovative spirits can be inspired.

\subsection{Conducting Comprehensive Quality Education Based on the “All-round Development” Principle}

Aiming at improving human quality, quality education is intended to achieve an all-round development of human beings. It emphasizes civil education, cognitive contents and methods, personality improvement, students' pioneering spirits, education on modern consciousness, especially innovativeness, international sights, independence, cooperative sense and so on. Human quality seems increasingly important with the more and more fierce competition in science nowadays. However, this issue has been neglected in our talent cultivation, which, based on the traditional pattern, focuses more on knowledge instead of comprehensive quality. Therefore, it is particularly important to strength our quality education during the process of cultivating applied talents. The following measures can be taken:

a). With newcomers' poor moral quality and basic knowledge, some classes and lectures in morality, writing and the like should be provided; some lectures in job guidance and legal knowledge should be organized to improve students' moral standards, independence in life and oral expression. In addition, students should be encouraged to take part in extracurricular activities such as science and technology innovation groups, various communities as well as social practice during vacations.

b). In terms of educational methods, the key should be switched from the teaching of knowledge to the cultivation of 
practical ability. Teachers can turn to various teaching methods, such as questions, heuristic teaching as well as discussions to encourage students' enthusiasm for learning. Besides, multi-media technology and computer network should be relied on to develop computer-assisted courseware for theoretical classes, to establish an interactive modern educational technology platform, to carry out teaching activities in an all-directional, three-dimensional and multi-channel way and hence to improve teaching efficiency and quality. In addition, students' abilities in logic and innovation as well as their potential learning abilities should be emphasized to equip them with rational thoughts, matter-of-fact attitudes, careful and responsible attitudes towards study as well as initiativeness. Meanwhile, their abilities in learning to perfect themselves and improving their comprehensive quality will be enhanced.

c). Great efforts should be made to develop high-quality education staff for the cultivation of talents with comprehensive quality. With teachers as a dominant element in the teaching process, teachers' knowledge structure and academic level will have direct impact on those of students. In order to cultivate high-level applied talents, teachers are expected to be equipped with profound theoretical knowledge and rich practical experience. The core of quality education should lie in both teachers and students because it is conducted by teachers and received by students with the overall purpose of improving students' comprehensive quality in an all-round way. Therefore, we should lay down and carry out effective policies and systems to attract most excellent staff to the field of comprehensive quality education.

d). In order to cultivate compound applied talents, compound specialties should be constructed and staff training should be innovated. As is demanded by our economic society, more efforts should be made to strengthen the construction of compound specialties and optimize staff structure for compound specialties. Meanwhile, teachers should be assisted to update their ideas and knowledge structure, to improve their comprehensive quality and to form their life-long learning abilities in order to help them to apply their innovative thought to innovate teaching methods and to provide a guarantee for fully conducting comprehensive quality education.

\section{Sticking to Harmonious Development to Fulfill Economic and Social Demands.}

Lying in a significant period of the conversion of social structure and economic system, new fields and careers appear from time to time, leading to constantly changing demands for talents. In the traditional talent cultivation pattern, schools seem isolated from the society, therefore, the talents they cultivate are not in conformance with market demands. Therefore, everything has to be changed, including schools' target orientation, curricular layout, specialty setting, talent cultivation plan, staff construction and some relevant management systems. All of these must be evaluated from the perspective of scientific development philosophy and conform to the demands for applied talents by the market. As a result, we should do something at the following aspects:

a). Aiming at the actual demands of social development, we should have a right orientation about our educational ideas and cultivation objectives first of all in accordance to the demands of social and regional economic development for high-quality talents. Some educational thoughts, such as matter-of-fact attitudes and high efficiency, should be manifested in our educational ideas.

b). When developing applied talents' abilities, the mastery and flexible application of basic knowledge should be emphasized. According to the traditional educational ideas, students have to master a lot of professional theories, which is not what the society needs. However, in the cultivation of applied talents, students should grasp and flexibly use professional skills with its ultimate goal of improving creativity and application abilities.

c). It is a complex systematic project to cultivate applied talents. In some basic links such as curricular setting and teaching material construction, basic, mature and practical knowledge as well as some unknown advanced fields should be paid attention to. In the teaching process, applied knowledge should be combined with scientific findings and creating new knowledge. Some current and potential social demands should be paid attention to constantly to correctly guide students to explore in the right direction, to inspire their desire for exploration as well to cultivate students' confidence and ability in self-development

d). We should construct a team to lay down cultivation plans for applied talents. Such as team, composed of experts in comprehensive quality education, curricular design, professional teaching, enterprise technology and human resources, will take part in all the links when establishing plans, in order to construct a pattern to cultivate applied talents conforming to social demands.

e). Bases for innovative practice should be set up to cultivate students' innovative sense and ability through practical teaching. More should be input into the construction of innovative base labs for students. Students should be encouraged to form extracurricular science and technology groups to organize colorful activities based on R\&D projects, in which they will be funded and guided by teachers.

\section{Sticking to Sustainable Development to Realize a New Leap in Talent Cultivation}

Students should be cultivated to be sustainably-developed talents with scientific thinking and methods for life-long learning. Talent cultivation refers to the development of people's quality, which should be sustainable. With the arrival 
of knowledge economy era, innovation and adaptability are emphasized. The key to whether human quality can have sustainable development lies in whether they have scientific thoughts and methods for life-long learning. The following efforts can be made in order to accomplish a leap in talent cultivation:

a). Students' life-long learning ability should be emphasized. Students are expected to learn how to learn new knowledge by themselves as well as skills and knowledge. Therefore, we should guide and encourage students to learn independently and to cultivate their independent learning ability. In addition, it should be fully realized that life-long learning is a permanent learning commitment formed by the economic society, in which students are the main body.

b). Students' innovative ability should be cultivated. Students' significance in educational activities should be emphasized and their innovative thoughts and spirits should be cultivated.

c). Students' social commitment and adaptability should be cultivated. Education in some non-intellectual elements such as emotion, will and personality, students' responsibility for the society, morality and psychological quality will be enhanced.

d). Students should also be educated to form right senses about the world, life and value, hence forming their sustainable internal quality. Surely, staff is expected to improve their quality through constant learning to provide a guarantee for students' sustainable development.

To sum up, only by correctly realizing the new situations and tasks for the development of socialist market with Chinese characteristics, scientifically analyzing the new opportunities, challenges, projects and contradictions facing the cultivation of applied talents, holding to the human-oriented basis, sticking to the principles emphasizing fulfilling market demands, being adapted to market changes, enhancing practical skills, improving staff standard and teaching quality, advancing in the direction of scientific development, adopting various, flexible and open talent cultivation patterns, combining teaching and social demands, improving students' ability in employment, can we accomplish our leap in the reform of high-level applied talent cultivation and develop more talents of that kind to construct a well-off society.

\section{References}

Chen, Jiefang. (2005). International Experience in Cultivating Applied Talents. Journal of Beijing Union University, Vol. 2.

Qin, Zuze, Tang, Shouyin, Yu, Guibang \& Huang, Junwei. (2002). Exploring Applied Undergraduate Education and Cultivating High-Level Applied Talents. Journal of Changchun Institute of Technology (Social Science), Vol. 3.

Xiang, Beili. (1998). Attention Called for to the Cultivation of Applied Talents in Regional Universities. Journal of Guangxi University (Social Science), Vol. 6.

Zhang, Baoxiu. (2002). Knowledge and Practice in Cultivating Applied Talents and Conducting Double-Certificate Education. Journal of Beijing Union University, Vol, 4.

Zhang, Rixin, Liang, Yuqing, Wang, Lingjiang, Lai, Li \& Xiao, Jun. (2005). Establishing New Cultivation Patterns for Applied Talents in Undergraduate Period. Journal of Chengdu University (Social Science), Vol. 2. 